Geological Map of the Union of South Africa. 4 Blätter, 1:1000000. Pretoria 1925. Blatt 2.

Hall, A. L. und Molengraaff, G. A. F.: The Vredefort Mountain Land ete. Amsterdam 1925.

JoNEs, G. C.: Correlation and other aspects of the exploited auriferous horizons on the Witwatersrand mining field. - Proc. Geol. Soc. S.-Africa 39, 1936.

Krahmann, R.: The Geophysical Magnetometric Investigations of West Witwatersrand Areas etc. - Trans. Geol. S.-Africa 39, S. 1_44, 1936. MELLoR, E. T.: Geol. Map of the Witwatersrand Goldfield. Aufgen. 1910/15, $1: 60000$.

--, - : The Geology of the Witwatersrand, an explan. of the Geol. Map. Pretoria 1917.

NeL, L. T.: Geological Map of the Cuntry around Vredefort. (Aufgen. 1923/25.) Mit Erl. 1:63 360.

-, - : Geological Map of the Klerksdorp-Ventersdorp Area. (Aufgen. 1931/34.) 2 Blätter mit Erl. 1935, 1:60000.

-, - : The Witwatersrand Rocks in the Klerksdorp and VentersdorpDistricts. - Trans. Geol. Soc. S.-Africa 37, S. 103. Johannesburg 1935.

Niggli, P. mit Lombaard, B.: Das Buschfeld als petrographische Provinz. - Schweiz. Min. Petr. Mitt. 13, S. 110-186, 1933.

Rogers, A. W.: Geological Map of the country around Heidelberg. Aufgen. 1918/21. 1:60 000, mit Erl.

Topographical Map of the Union of South Africa. 1:500 000.

Willemse, J.: The Petrography and Tectonies of the Pretoria_Johannesburg-Granite. - Trans. Geol. Soc. S.-Africa 36, S. 1-27, 1984.

\title{
Berichtigung zu Tafel IV
}

In der Unterschrift zu der Tafel muß es statt „Nach L. T. Vel“ heißen: „Nach L. T. Nel“. 